DOI: doi.org/10.21009/IJLECR.051.06

Received: 20 January 2019

Revised: 1 February 2019

Accepted: 12 March 2019

Published: 30 June 2019

\title{
DESIGNING ICT COMPETENCES-INTEGRATED SYLLABUSES OF PRACTICAL KEY TEACHING COMPETENCE FOR ENGLISH LANGUAGE EDUCATION STUDY PROGRAM
}

\author{
Khilda Shopia $^{1, a)}$, Ifan Iskandar ${ }^{1, b)}$ \\ Master Program of English Language Education Study Program \\ Universitas Negeri Jakarta, Jakarta, Indonesia ${ }^{1)}$ \\ khilda.shopia@mahasiswa.unj.ac.id ${ }_{2}{ }_{2}$ ifaniskandar@unj.ac.id ${ }^{\text {b) }}$
}

\begin{abstract}
The needs of the ICT competences in education become the consideration in infusing ICT to the process of teaching and learning. This study was conducted to design the ICT competencesintegrated syllabuses of Practical Key Teaching Competences for English Language Education Study Program. The analysis of ICT competences used UNESCO ICT Competences Framework, European Profiling Grid and International Society for Technology in Education. The design employed Richey and Klein, Borg and Gall, and Wademan model of DDR which were modified into four steps; need analysis, prototype syllabus design, evaluation and revision. Eight existing syllabuses of Practical Key Teaching Competence were analyzed. They are the syllabuses of Lesson Course Planning, Teaching Practicum and Classroom Management from some Universities in Indonesia. The findings showed that most of the existing syllabuses were not completely ICT competences integrated. ICT competences appeared only in learning outcomes, course learning outcomes, indicator, materials, teaching method, media of learning and assessment but not in basic information, course description, policy, grading and reference. The dominant level of ICT competences applied in the existing syllabuses was Technology Literacy. Then, it was found eleven steps of procedure to design syllabuses of Practical Key Teaching Competence integrated ICT competences. The prototype syllabuses integrated ICT competences were designed. The entire components of the designed syllabus infused ICT competences except Time Allocation. The proposed syllabuses implemented types of integrated syllabus for Lesson Course Planning and Classroom Management. Then, task based syllabus was used for Teaching Practicum that integrated by ICT.
\end{abstract}

Keywords: ICT-Competences, Practical key teaching Competence Syllabuses, EPG, UNESCO ICT Competences Framework for Teacher.

The usage of technology in education gives the contribution a lot in pedagogical aspects and curriculum to lead the effective learning (Ghavifekr, Athirah, Rosdy, \& Teaching, 2015, p. 2). Information, Communication and Technology (ICT) literacy is one of the skills described in $21^{\text {st }}$ century skill (Education \& Skills, 2010). Integrating technology effectively is the challenge for the teacher. The teacher use ICT to modify learning based on the students' need, provide students to access many sources to become learners centered, support the students' learning process 
through E-learning management (Education \& Skills, 2010). Internet device such as Google, Wikipedia, Blogs, You tube usually used by the students in accessing information or relevant materials that support students' learning (Duffy, 2007).Then, the development of Industrial Revolution 4.0 in education appeared. In Education 4.0, teachers must prepare students not only with knowledge and information, but also by promoting creativity, refining students' critical thinking and problem-solving skills, also interacting and communicating across the globe by using ICT (Anealka Aziz Hussin, 2018, p. 1). The previous study also explained the usage of ICT todays' technology is essential tools for teaching and learning to support the teaching method and activities in the teaching and learning process (Jung, 2013, pp. 94-101).

UNESCO ICT framework also elaborates the ICT competences for the teacher. It is divided into three approaches as the process how the teacher identify and implement ICT competences in teaching and learning process such as Technology Literacy, Knowledge Deepening and Knowledge Creation (UNESCO, 2011). The integration of ICT competences means the implementation and infusion the right usage of ICT competences into teaching and learning process including in syllabus (Ghavifekr et al., 2015, p. 3). Syllabus is as the guidance in the process of teaching and learning in the classroom that help the teacher to achieve the goals of learning. In considering the needs of ICT competences to prepare the students in $21^{\text {st }}$ century and Education 4.0, ICT competences integrated syllabus design to guide the teacher in the process of teaching and learning.

Practical Key Teaching Competence is one of the competences that must be mastered by preservice teacher. It is a must to master in preparing the teaching set in the classroom, comprehend in designing lesson plan, practicing the planning in the classroom and managing the class to organize the class situation effectively and appropriately (Voss, 2004, p. 5). The courses of Practical Key Teaching Competence are identified based on European Profiling Grid (EPG) qualification in key teaching competence category. It focuses to three subjects matter such as Lesson Course Planning, Teaching Practicum and Classroom Management. It means, it will be designed the syllabuses of the three courses above integrated by ICT competences. Then, the research questions are formulated. The main research question to be addressed in this research is "How are the ICT competences-integrated syllabuses of Practical Key Teaching Competence for English Language Education Study Program (ELESP)?”. The sub research questions as follows:

1. To what extent are the ICT competences integrated in the existing Practical Key Teaching Competence syllabuses for English Language Education Study Program?

2. How are the ICT competences integrated into the syllabuses of Practical Key Teaching Competence syllabuses for English language Education Study Program?

3. How are the designs of ICT competences- integrated syllabuses of Practical Key Teaching Competence for English Language Education Study Program?

Based on the research questions above, this research is intended to design the ICT competences-integrated syllabuses of Practical Key Teaching Competence for ELESP in order to prepare the teacher' ICT competences and fulfill the needs of ICT competences to face the challenges in $21^{\text {st }}$ century and the needs of IR 4.0 in educational area.

\section{METHOD}

In conducting the study, Design and Development Research design (DDR) is used. As the purpose of the study is to design the syllabuses of Practical Key Teaching Competence integrated ICT competences. As explained by Richey and Klein that DDR is as the systematic process to build the empirical basis of design, development and evaluation process in order to create the instructional and non- instructional products and tool (Richey and Klein, 2007). The researcher adapts the small scale of DDR model. The description of the small scale of DDR' model as 
follows;

1. Need analysis formulated from the expert' design; process analysis by Richey and Klein (2007), assess needs to identify goals by Borg and Gall (2003), and problem identification by Wademan (2005). Need analysis is the process to collect the information from relevant theories (literature review) and document analysis of the existing syllabuses of Practical Key Teaching Competences. Literature review provided the analysis related with syllabus design, types of syllabus, component of syllabus, the coverage of Practical Key Teaching Competence, ICT competences for Practical Key Teaching Competence. Then, document analysis used to enrich the researcher' reference, the analysis of the existing syllabuses of Practical Key Teaching Competence for ELESP conducted in deciding ICT indicators, ICT competences for Practical Key Teaching Competence and deciding syllabus design model, key teaching principles for Practical Key Teaching.

2. Preliminary prototypical syllabuses design formulated from the three experts; Richey and Klein (2005), Borg and Gall (2003) and Wademan (2005). It is the process as the result of need analysis. After finding the gap between the literature review and the existing syllabuses of Practical Key Teaching Competence, the prototype syllabuses can be produced.

3. Evaluation formulated to evaluate and validate the prototypes syllabuses design of Practical Key Teaching Competence. It is also as the process of expert judgment about the prototype syllabuses design. It is formulated based on the three expert designers; Richey and Klein (2005), Borg and Gall (2003) and Wademan (2005).

4. Revision will be conducted after the process evaluation. The experts give their judgments and advices about the preliminary syllabuses to improve the quality of prototype syllabuses of Practical Key Teaching Competence.

The process DDR in this research is shorter than the entire experts' process design. The process of DDR can be stopped and not follow the complete process because it consider the situation that arise as the study progress so that the researcher can implement the design with flexibility based on the research' situation and need (Richey and Klein 2005). Then, the figure below illustrates the scheme of DDR model as follows;

\section{Figure 1 The Scheme of Research Design Model}

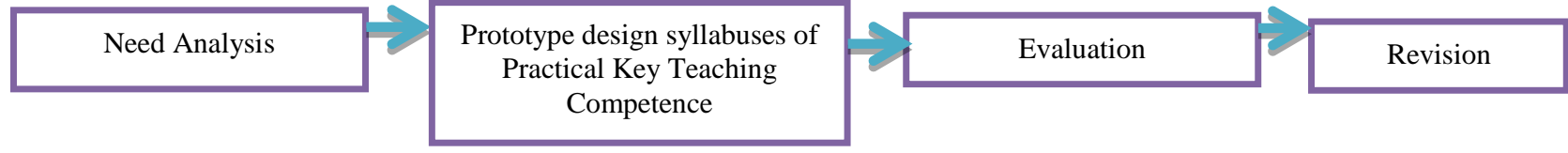

Then, the specific data, data sources and instrument are used in the process analyzing as follows:

Table 1 Data, Data Sources and Instruments

\begin{tabular}{|c|c|c|c|c|}
\hline DDR Steps & $\begin{array}{c}\text { Sub- } \\
\text { Research } \\
\text { Questions } \\
\text { No. }\end{array}$ & Data & Data Source & Instrument \\
\hline $\begin{array}{l}\text { Need } \\
\text { Analysis }\end{array}$ & Sub RQ 1 & $\begin{array}{l}\text { Syllabus components and } \\
\text { related theories of ICT } \\
\text { competences integrated } \\
\text { Practical Key Teaching } \\
\text { competence syllabus }\end{array}$ & $\begin{array}{l}\text { - Existing Practical } \\
\text { Key Teaching } \\
\text { syllabuses of } \\
\text { undergraduate } \\
\text { students of ELESP } \\
\text { in Indonesia } \\
\text { - Literature review } \\
\text { about ICT } \\
\text { Competences, } \\
\end{array}$ & $\begin{array}{l}\text { Researcher, } \\
\text { ICT } \\
\text { competence - } \\
\text { integrated } \\
\text { syllabus } \\
\text { indicators and } \\
\text { table of } \\
\text { analysis }\end{array}$ \\
\hline
\end{tabular}




\begin{tabular}{|c|c|c|c|c|}
\hline & & & $\begin{array}{l}\text { syllabus design and } \\
\text { Practical Key } \\
\text { Teaching } \\
\text { Competence }\end{array}$ & \\
\hline $\begin{array}{l}\text { Preliminary } \\
\text { prototypes } \\
\text { the syllabus } \\
\text { design }\end{array}$ & Sub RQ 2 & & \multirow{3}{*}{$\begin{array}{l}\text { The result of analysis } \\
\text { from the existing } \\
\text { syllabuses and related } \\
\text { ICT and EPG } \\
\text { Descriptor }\end{array}$} & \\
\hline Evaluation & Sub RQ 3 & $\begin{array}{l}\text { Components of Practical } \\
\text { Key Teaching } \\
\text { Competence syllabuses } \\
\text { integrated by ICT } \\
\text { competences. }\end{array}$ & & \multirow{2}{*}{$\begin{array}{l}\text { Researcher, } \\
\text { Syllabus } \\
\text { experts }\end{array}$} \\
\hline Revision & Sub RQ 3 & $\begin{array}{l}\text { Statement from the result } \\
\text { of evaluation or expert } \\
\text { judgment containing } \\
\text { suggestions and } \\
\text { feedbacks from the } \\
\text { experts }\end{array}$ & & \\
\hline
\end{tabular}

\section{RESULTS AND DISCUSSION}

Some analyses are conducted to get the result of study. The analysis was conducted to get the answer of how the ICT competences-integrated syllabuses of Practical Key Teaching Competence for English Language Education Study Program (ELESP). After formulating and analyzing the data descriptively, it can be found findings in this research; the analysis result of existing syllabuses, the procedure in integrating ICT competences in syllabuses of Practical Key Teaching Competence, and the prototype of the syllabuses of Practical Key Teaching Competence design integrated ICT competences.

\section{Existing Syllabuses of Practical Key Teaching Competence}

Existing syllabuses of Practical Key Teaching Competence were used to answer the first sub research question to analyze how far ICT competences integrated, to analyze the syllabus components were employed dominantly by some universities in Indonesia and to analyze the EPG descriptor for key teaching competence category. Then, the result of analysis will be used to design the prototype syllabuses design of Practical Key Teaching Competence. In analyzing syllabuses infused ICT competences, it was needed ICT competences' indicators. ICT competences' indicators were formulated for general of language teacher and Practical Key Teaching Competence. It employed the UNESCO ICT Competency by using the three approaches; Technology Literacy, Knowledge Deepening and Knowledge Creation and some theories used in formulating the indicator. The result showed there were 196 indicators that can be analyzed and matched with Practical Key Teaching Competence. Then, there were 87 indicators of ICT competences for Practical Key Teaching Competence to analyze the existing syllabuses Practical Key Teaching Competence integrated by ICT. The result of analysis ICT competences in the existing syllabuses showed as follows; (1).ICT competences implicitly used in the syllabus (RPS), (2).ICT competences were used to access relevant material through internet device, (3).ICT competences were used to support the teaching and learning process by using some hardware in the classroom, to support the students' and teachers' presentation such as Laptop, LCD, projector, infocus, (4).ICT competences were used to support the teaching and learning process by using some software in the 
classroom such as the ability to operate Microsoft Office Word and Presentation. (5).ICT competences were used to facilitate the students in making a paper, essays, presentation slides and discussion report, (6). The ability in sharing information through ICT, (7). The ability in creating a lesson through digital source. The analysis' result will be used as the analysis how ICT competences used in the syllabus and it can be used as the reference in infusing ICT competences into the prototype syllabus design. The result in each university as follows;

Table 1 The Analysis Result of ICT competences in the Existing Syllabuses of Practical Key Teaching Competence

\begin{tabular}{|c|c|c|}
\hline No. & & $\begin{array}{l}\text { ICT competences in the Existing Syllabuses of Practical Key Teaching } \\
\text { Competence. }\end{array}$ \\
\hline 1. & $\begin{array}{l}\text { University A } \\
\text { (RPS } 1 \text { \& 2) }\end{array}$ & $\begin{array}{l}\text { - ICT competences as a tools and resources. } \\
\text { - ICT tools which is used such as laptop, projector, Microsoft word, } \\
\text { Microsoft presentation, and internet device. } \\
\text { - Component of syllabus in RPS } 1 \text { explained ICT competences in learning } \\
\text { outcomes, course learning outcomes, indicator, materials, teaching method } \\
\text { and assessment. } \\
\text { - ICT competences were described implicitly in all of the components above } \\
\text { - Technology literacy was as the dominant approaches used in RPS } 1 \text { and } 2 \\
\text { based on the three approaches of UNESCO framework. }\end{array}$ \\
\hline 2. & $\mathrm{~B}$ & $\begin{array}{l}\text { - ICT competences were used to look for the materials and sources in the } \\
\text { internet to support the teaching and learning process and achieve the } \\
\text { learning objective. } \\
\text { - ICT competences in this RPS mean ICT as a tools and sources } \\
\text { - ICT competences explained in learning outcomes, material, teaching } \\
\text { method and assessment. } \\
\text { - It was described implicitly in each component } \\
\text { - Technology Literacy was as the dominant approaches used in RPS } 3 \text {. }\end{array}$ \\
\hline 3. & $\begin{array}{l}\text { University C } \\
\text { (RPS 4) } \\
\text { RPS for } \\
\text { Lesson } \\
\text { Course } \\
\text { Planning. }\end{array}$ & $\begin{array}{l}\text { - ICT as the tools and resource. } \\
\text { - RPS mentions some hardware used as the media of learning such as } \\
\text { projector and OHP. } \\
\text { - The components syllabus that integrated ICT competences were materials, } \\
\text { teaching method, media of learning and assessment. } \\
\text { - Then, Technology Literacy was as the dominant used }\end{array}$ \\
\hline 4. & 5) & $\begin{array}{l}\text { - The RPS describes the learning objective and course description clearly in } \\
\text { which ICT competences are described implicitly in both of them. } \\
\text { - Media used such as LCD projector and other relevant instructional media } \\
\text { will be used to optimize teaching and learning process. } \\
\text { - ICT competences were used to look for the materials and sources in the } \\
\text { internet to support the teaching and learning process and achieve the } \\
\text { learning objective. } \\
\text { - ICT competences elaborated in components syllabus such as learning } \\
\text { outcomes, materials, media of learning and assessment. } \\
\text { - Technology Literacy was as the dominant approaches used in RPS } 3 \text {. }\end{array}$ \\
\hline 5. & 6) & $\begin{array}{l}\text { - ICT competences are elaborated clearly in this RPS. It is provided several } \\
\text { link of website that can be accessed by the students to support the students' } \\
\text { understanding. }\end{array}$ \\
\hline
\end{tabular}




\begin{tabular}{|c|c|c|}
\hline & & $\begin{array}{l}\text { - ICT competences employed in this RPS such as the ability to employed ICT } \\
\text { as a tool, it can be hardware and software, the ability to find and access } \\
\text { relevant materials support their understanding. } \\
\text { - It is described implicitly in learning outcomes, course learning outcomes, } \\
\text { materials, teaching method, media of learning, assessment, course policy } \\
\text { and reference. } \\
\text { - Knowledge deepening is used dominantly in operating an accessing ICT. }\end{array}$ \\
\hline 6. & $\begin{array}{l}\text { University F } \\
\text { (RPS 7) } \\
\text { RPS for } \\
\text { Classroom } \\
\text { Management. }\end{array}$ & $\begin{array}{l}\text { - ICT competences can be seen as the ability to find and access the relevant } \\
\text { material explained in the references explicitly. } \\
\text { - The hardware were used such as LCD presentation, laptop and Microsoft } \\
\text { presentation to support the students' and teacher presentation in the } \\
\text { classroom. } \\
\text { - Syllabus component integrated of ICT in learning outcomes, materials, } \\
\text { teaching method, media of learning, assessment and references. } \\
\text { - Technology Literacy was as the dominant used and it was followed by } \\
\text { Knowledge Deepening and Creation. } \\
\text { - The ICT competences could be seen in the process teaching and learning in } \\
\text { term ICT as a tool and ICT as a reference. }\end{array}$ \\
\hline 7. & $\begin{array}{l}\text { University G } \\
\text { (RPS 8) } \\
\text { RPS of } \\
\text { Classroom } \\
\text { Management. }\end{array}$ & $\begin{array}{l}\text { - This RPS support ICT competences in the activity of the classes. It can be } \\
\text { seen in facilitating the link website to support students in comprehending } \\
\text { the material discussion or topic. Then, it is also provided the electronic book } \\
\text { for students. } \\
\text { - It was described implicitly in learning outcomes, course learning outcomes, } \\
\text { materials, teaching method, media of learning, assessment and reference. } \\
\text { - Then, Knowledge Deepening was used dominantly in operating and } \\
\text { accessing ICT. }\end{array}$ \\
\hline
\end{tabular}

Table 2 The Analysis Result of Syllabus Component and EPG Development Phase in the Existing Syllabuses of Practical Key Teaching Competence

\begin{tabular}{|c|c|c|}
\hline & Syllabus Components in the Existing Syllabuses & $\begin{array}{c}\text { EPG Qualification } \\
\text { of Key Teaching } \\
\text { Competence in } \\
\text { Syllabuses of } \\
\text { Practical Key } \\
\text { Teaching } \\
\text { Competence }\end{array}$ \\
\hline $\begin{array}{l}\text { University } \\
\text { A (RPS } 1 \\
\& 2)\end{array}$ & $\begin{array}{l}\text { RPS } 1 \\
\text { Basic Information, Standar Kompetensi, Kompetensi } \\
\text { Dasar, Indicator, Time Allocation, Course Materials, } \\
\text { Course Outline, Teaching Learning Activities, Assessment, } \\
\text { Media of Learning, References. } \\
\text { RPS } 2 \\
\text { Basic Information, Course Content, Standar Kompetensi, } \\
\text { Kompetensi Dasar, Indicator, Learning Outcomes, Course } \\
\text { learning Outcomes, Time Allocation, Course Materials, } \\
\text { Course Outline, Teaching Learning Activities, Assessment, } \\
\text { Media of Learning, References. }\end{array}$ & $\begin{array}{l}\text { Development Phase } \\
1.1\end{array}$ \\
\hline
\end{tabular}




\begin{tabular}{|c|c|c|}
\hline $\begin{array}{l}\text { University } \\
\text { B (RPS 3) }\end{array}$ & $\begin{array}{l}\text { Basic Information, Course Content, Learning Outcomes, } \\
\text { Time Allocation, Course Materials, Course outline, Media } \\
\text { of Learning, References }\end{array}$ & $\begin{array}{l}\text { Development Phase } \\
2.1\end{array}$ \\
\hline $\begin{array}{l}\text { University } \\
\text { C (RPS 4) }\end{array}$ & $\begin{array}{l}\text { Basic Information, Indicator, Time Allocation, Course } \\
\text { Materials, Course Outline, Teaching Learning Activities, } \\
\text { Assessment, Media of Learning, References. }\end{array}$ & $\begin{array}{l}\text { Development Phase } \\
2.1\end{array}$ \\
\hline $\begin{array}{l}\text { University } \\
\text { D (RPS 5) }\end{array}$ & $\begin{array}{l}\text { Basic Information, Course Description, Learning } \\
\text { Outcomes, Time Allocation, Course Materials, Course } \\
\text { Outline, Teaching Learning Activities, Assessment, Media } \\
\text { of Learning, Evaluation Criteria/ grading, References. }\end{array}$ & $\begin{array}{l}\text { Development Phase } \\
2.2\end{array}$ \\
\hline $\begin{array}{l}\text { University } \\
\text { E (RPS 6) }\end{array}$ & $\begin{array}{l}\text { Basic Information, Course Description, Learning } \\
\text { Outcomes, Course Learning Outcomes, Time Allocation, } \\
\text { Course Materials, Course Outline, Teaching Learning } \\
\text { Activities, Assessment, Media of Learning, Evaluation } \\
\text { Criteria/ Grading, Course Policy and References. }\end{array}$ & $\begin{array}{l}\text { Development Phase } \\
2.2\end{array}$ \\
\hline $\begin{array}{l}\text { University } \\
\text { F (RPS 7) }\end{array}$ & $\begin{array}{l}\text { Basic Information, Course Description, Kompetensi Dasar, } \\
\text { Indicator, Time Allocation, Course Materials, Course } \\
\text { Outline, Teaching Learning Activities, Assessment, Media } \\
\text { of Learning, References. }\end{array}$ & $\begin{array}{l}\text { Development Phase } \\
2.1\end{array}$ \\
\hline $\begin{array}{l}\text { University } \\
\text { G (RPS 8) }\end{array}$ & $\begin{array}{l}\text { Basic Information, Course Description, Course Content, } \\
\text { Learning Outcomes, Course Learning Outcomes, Time } \\
\text { Allocation, Course Materials, Course Outline, Teaching } \\
\text { Learning Activities, Assessment, Media of Learning, } \\
\text { Evaluation Criteria/ Grading, References. }\end{array}$ & $\begin{array}{l}\text { Development Phase } \\
2.2\end{array}$ \\
\hline Discussion & $\begin{array}{l}\text { After getting the result of analysis, it can be shown that in } \\
\text { designing a new syllabuses employed some components in } \\
\text { the existing syllabuses such as basic information, course } \\
\text { description, learning outcomes, course learning } \\
\text { outcomes, indicator, material, teaching method, media } \\
\text { of learning, time allocation and adds another component } \\
\text { such as course policy and time allocation to be included } \\
\text { in the syllabuses of Practical Key Teaching Competence. }\end{array}$ & $\begin{array}{l}\text { Based on the } \\
\text { analysis result of } \\
\text { EPG development } \\
\text { phase in the existing } \\
\text { syllabus will be used } \\
\text { as the standard in the } \\
\text { prototype of syllabus } \\
\text { design. Then, the } \\
\text { analysis result } \\
\text { inferred that } \\
\text { Development Phase } \\
\text { 2.2 will be used in } \\
\text { designing the } \\
\text { prototype syllabuses. }\end{array}$ \\
\hline
\end{tabular}

\section{The Procedures of Integrating ICT Competences in the Practical Key Teaching} Competence Syllabuses for ELESP

The procedure in integrating ICT Competences in syllabuses of Practical Key Teaching Competences is to answer the second sub- research question. The procedure in integrating ICT Competences in syllabuses as follows

1. Identifying the indicators of ICT competences based on UNESCO framework, International Society for Technology in Education (ISTE), EPG descriptors, and other relevant literature review. 
2. Identifying the indicators of Practical Key Teaching Competence based on EPG qualification of Key Teaching Competence and other relevant literature review.

3. Selecting the indicators of ICT competences related to Practical Key Teaching competence.

4. Analysis of syllabus design, types of syllabus, components of syllabus based on literature review. This analysis has been conducted during the literature review.

5. Analyzing the components of existing syllabuses of Practical Key Teaching Competence in each university corresponds with EPG' descriptors in order to get the qualification of the teaching competence.

6. Selecting the components of existing syllabuses of Practical Key Teaching Competence and other relevant literature review such as Peraturan Kurikulum Pendidikan Tinggi (2016), Altman, Dillon and Davis' theory of syllabus components to be designed in the purposed - syllabuses of Practical Key Teaching Competence. The result of analysis infer that the components of syllabuses are Basic Information (C1), Course Description (C2), Learning Outcomes (C3), Lesson Learning Outcomes (C4), Indicator (C5), Materials (C6), Teaching Method (C7), Time allocation (C8), Media of Learning (C9), Assessment (C10), Resources (C11), and Course Policies (C12).

7. Adjusting indicators of ICT competences and components of existing syllabus which accommodate ICT competences.

8. Infusing the ICT competences into the syllabus components of Practical Key Teaching Competence. It is the design of new syllabuses of Practical Key Teaching Competence integrated ICT competences.

9. Design ICT Competences- integrated syllabuses of Practical Key Teaching Competence that cover the syllabuses for Lesson Course Planning, Teaching Practicum and Classroom Management. It is the answer for the third sub-research question.

10. Evaluate the prototype syllabus design Practical Key Teaching Competence Integrated ICT competences in which it will be revised for the better new syllabus design.

11. Revise the designs of syllabuses of Practical Key Teaching Competence integrated ICT competences.

\section{The Designs of ICT competences integrated - syllabuses of Practical Key Teaching Competence for English Language Education Study Program (ELESP)}

The result of analysis showed that ICT Competences that can be integrated in syllabuses of Practical Key Teaching Competence as follows:

1. Prepare instructional materials for students using basic technology tools (e.g., word-processing software, presentation software, and software that creates Internet resources).

2. Create lesson with download texts, picture and graphics.

3. Search for potential teaching material on the internet

4. Use ICT resources for teacher professional development and learning.

5. Use ICT in presenting the instructional content and guiding the teaching and so on.

6. Use ICT to access and share resources to support students' activities and their own professional learning.

7. Organize the clear exercise and set of instruction for the students.

8. Facilitate the appropriate ICT tools in giving fast feedback to students' error.

9. Implement ICT tools for constructing and sharing new concrete information.

10. Use a network for supporting students collaboration within and beyond classroom.

11. Use ICT to support the teaching and learning process by using some hardware in the classroom such as Laptop, LCD, projector, infocus.

12. Use ICT tools to develop students higher order thinking and creativity through internet device. 
Then, according to the result above, it can be formulated the ICT competences in designing prototype syllabus design for Practical Key Teaching Competence. Then, the syllabus components which were used in the prototype design follow the result of analyzing the existing syllabus and theory of syllabus components as follow;

1. Basic Information

2. Course Description

3. Course Learning outcomes- CPMK

4. Lesson learning outcome- SUB CPMK

5. Indicator

6. Course materials
7. Teaching Method

8. Time Allocation

9. Media of Learning

10. Assessment

11. Course Policy

12. Resources

Those syllabus components above were infused ICT competences expect Time Allocation. Macalister and Nation' Model is used in designing the syllabus. The types of Integrated syllabuses (Content based and Task based syllabus) was employed for syllabuses of Lesson Course Planning and Classroom Management. It is employed the types of Integrated syllabuses based on the consideration that Lesson Course Planning discuss about content or topic in supporting the students to write a detail plan in the end of the course. Content based syllabus employed in students' comprehending about the subject matter. Then, task based syllabus was used in assigning the student to produce the written detail plan and also the theory or steps in writing the lesson plan. Similarly with the Lesson Planning that types of integrated syllabus employed for syllabuses of Classroom Management, it was used in understanding the content and giving the task to measure student' comprehending. In Teaching Practicum, dominantly, the students practice their teaching competence so that it was used task based syllabus because the students directly practice their teaching competence. The types of syllabus should be decided to make easier in designing the prototypes of syllabuses in each course in Practical Key Teaching Competence.

The designs of Syllabuses of Practical Key Teaching Competence were evaluated by some experts. Then, the evaluation sheet provided the ICT competences descriptors and the statements from the syllabus components to be reviewed and evaluated. The results of experts' judgment in evaluating the syllabuses design as follows; (1).There were some ICT competences descriptors did not relevant with the syllabus components so that they need to be omitted, (2).ICT competences descriptors should be mentioned the level of ICT competences explicitly based on UNESCO ICT Framework such as Technology Literacy, Knowledge Deepening and Knowledge Creation, (4).In the syllabus component of Course Learning Outcomes, it should be stated explicitly the medias are needed in teaching and learning process in order to validate the ICT competences descriptor clearly, (5).In the syllabus component of Teaching Method, ICT competences and ICT tools should be explained explicitly. They need to be stated in detail how each method will be delivered in teaching and learning process and what ICT tools will be used to support the teaching method so that ICT competences descriptors can be validated, (6). Similarly in the syllabus component of Media of Learning, ICT competences and ICT tools should be explained clearly and explicitly and Assessments should be presented parallel.

Based on the result of evaluation process from the experts' judgment above, the three prototypes syllabuses of Practical Key Teaching Competence and the evaluation sheets have been revised. The three prototypes syllabuses of Practical Key Teaching Competence were revised in term of the ICT competences were explained in the syllabus component more detail and specific.

\section{CONCLUSION}

In conclusion, it can be inferred that ICT competences can be infused in the syllabuses of Practical Key Teaching Competence. The conclusion can be drawn. First, by analyzing the existing syllabuses of Practical Key Teaching Competence, the result showed that the ICT competences 
indicators are mostly integrated in the components of Learning Outcomes, Course Learning Outcomes, Indicator, Materials, Teaching Method, Media of Learning and Assessment that integrated implicitly and explicitly in which ICT competences occurred as the tools and resources to access relevant materials. The existing syllabuses have been indicating all levels of ICT competences; Technology Literacy, Knowledge Deepening and Knowledge Creation. However, Technology Literacy is mostly applied in the syllabuses from eight universities. Second, it can be concluded there are eleven steps of procedure in designing ICT competences- integrated syllabuses of Practical Key Teaching Competence. The syllabus components can be integrated ICT implicitly and explicitly in new prototype syllabuses of Practical Key Teaching Competence such as basic information, course description, learning outcomes, course learning outcomes, lesson learning outcomes, indicator, materials, teaching method, media of learning, assessment, course policy, and resources. Third, the proposed syllabuses of Lesson Course Planning, Classroom management and Teaching practicum integrated ICT competences are designed. Type of Integrated syllabus was used to design syllabuses of Lesson Course Planning and Classroom Management and Task based syllabus employed in Teaching Practicum. The proposed-syllabuses of Practical Key Teaching Competence are integrated by ICT competences implicitly and explicitly into the entire components of syllabus except Time Allocation.

\section{REFERENCES}

Aglazor, G. (2017). The Role of Teaching Practice in Teacher Education Programmes : Designing Framework For Best Practice, 16, 101-110.

Anealka Aziz Hussin. (2018). Education 4.0 Made Simple: Ideas For Teaching. International Journal of Education and Literacy Studies, 6(3), 92-98. https://doi.org/10.7575/aiac.ijels.v.6n.3p.92

Cakiki, D. (2018). The use of ICT in Teaching English as a Foreign Language . Journal of Language an Linguistic Studies EFL Teacher, (January).

Davis, B. G. (2009). Tools for Teaching. Josey Bass Higher and Adult Education Series.

Duffy, P. (2007). Engaging the YouTube Google-eyed generation: Strategies for using web 2.0 in teaching and learning. ECEL 2007: 6th European Conference on e-Learning, 6(2), 173-182.

Education, T., and Skills, C. (2010). 21St Century Knowledge and. Education, (September), 40. https://doi.org/10.1787/9789264193864-en

Fink, S. B. (2012). The Many Purposes of Course Syllabi: Which Are Essential and Useful?, 1(1), 1-12. Retrieved from http://www.syllabusjournal.org/article/view/10147

Gall, M. D., P.Gall, J., and Borg, W. R. (2003). Educational Research_ An Introduction (7th Edition)-Allyn \& Bacon (2003).

Ghavifekr, S., Athirah, W., Rosdy, W., and Teaching, W. A. W. (2015). Teaching and Learning with Technology: Effectiveness of ICT Integration in Schools Teaching and Learning with Technology : Effectiveness of ICT Integration in Schools. International Journal of Research in Education and Science (IJRES), 1(2), 175-191.

Graves, K. (2000). Designing Language Courses. Hainle \& Hainle Publisher 